\title{
The Aesthetics and Attainability of Cultural Cohesion: The Metaphorical Compositional Structure of Oresteia and Acropolis of Athens
}

\author{
By Vladimir Mako*
}

\begin{abstract}
The aim of this paper is to investigate the essence of tripartite compositional structures as developed in several important cultural monuments of classical Greek art from the fifth century BCE. This structure appears as a possible mutual aesthetic approach to a metaphorical interpretation of particularly-shaped mythological meanings, revealing the essential cultural and social beliefs and values of the period. In that context, the discussion on Aeschylus's trilogy Oresteia and the appearance of three essential forms of Athena's holy places on the Acropolis of Athens can help us understand one of many aspects of cohesion of cultural and aesthetic expression of that period. Moreover, this investigation focuses attention on the possible aspects of aesthetic development of a society's fundamental ideals and the forms of their variable appearances.
\end{abstract}

\section{Introduction}

After suffering extreme destruction of their city by the Persians in $479 \mathrm{BCE}$, and then experiencing glorious victory over the same enemy in the Battle of Salamis, in the following decades the people of Athens developed a way of thinking, establishing new cultural, philosophical, ethical, aesthetical and political ideas. However, it seems that such differentiation between fields of human social activities was not particularly evident in the minds of people of the Athenian classical period. One may think that there was a developed coherent understanding of what are the essential manifestations of human existence on the social and personal levels, but clearly under the umbrella of the most important political expression of these essentials. It seems that by equating the fundamental aspect of human existence with the notion of homo politicus, the Athenians of the Classical fifth century established only the variables of a coherent idea as expressions in different fields of social and artistic activities.

The final results of such a process should be understood as manifestations of a number of perceptual characteristics and qualities not separated by developing divergent ideas regarding issues of human existence, but formed in line with the very nature of the fields of the praxis itself. Consequently, it seems possible for us to gain insight into the fundamental unity of important social, political and aesthetic ideas within the diversity of their perceptual manifestations. Actually, it could be thought of as a search for particular aspects of cultural cohesion, manifested in the most important expressions of the life of the polis and its nature.

For the purpose of our discussion, and at the risk for simplifying such an important issue, we should focus our attention on two examples of final classical

*Professor, University of Belgrade, Serbia. 
perfection: the Greek tragedy and the Acropolis of Athens. In this statement, Rodenwaldt expressed the general opinion of many scholars that the Attic drama and the fifth-century classical architecture of Athens are the highpoints of its democratic and cultural development. ${ }^{1}$ However, regarding the art of tragedy, in our analysis we will apply a more constrained selection of examples. In regard to the period of their appearance and the cultural influence on generations of artists, and generally on the people of Athens as the political body of the polis, it seems that Aeschylus' Orestheia trilogy, performed in $458 \mathrm{BCE}$, would be the most practical example for our analytical process.

\section{Aeschylus' Oresteia}

The origin, social significance, structure, and general cultural importance of the art of tragedy, and particularly the work of Aeschylus, are well known. However, there are several aspects essentially relevant to our discussion, to which we need to pay attention in order to point out the particularities of the issue in question.

In his book, Albin Lesky emphasized the fundamental aspects configuring the structure and the meaning of Greek tragedy. For our discussion the notion of the epic as the perception of life as a chain of events is of particular importance. ${ }^{2}$ It points out the dynamic sense of life which is embedded in the way of thinking, developed by the Greeks of the classical period, and according to which tragedy was structured as the form of action, or imitation of action as Aristotle called it. ${ }^{3}$ Accordingly, tragedy is a negation of narrative and it gained its gravity, its dignity, its poise, through the heroic myth. ${ }^{4}$

Regarding these essential notions, Lesky generally recognizes three prerequisites for tragic effect, which in a way establish the fundamental character of drama and its aesthetic communication with the audience. First, the tragic effect should be built on the dignity of the fall. ${ }^{5}$ The second prerequisite is linked to the sense that the acknowledgement of the tragic should be relevant to the actual world the audience live in. ${ }^{6}$ The third prerequisite asks the protagonist to consciously accept the agony and suffering as a result of decisions provoked by the conflicts developed in the play. ${ }^{7}$ The named three prerequisites fully emphasize empathy as the core of the structure of the tragic play and its role in a transmutation of life, which according to Lesky, presence convergence of the inner forces of Dionysian religion and events of a political nature. ${ }^{8}$

However, focusing his attention on Oresteia, particularly on the final act of The Eumenides, Lesky emphasizes the feeling of reconciliation as an important

1. G. Rodenwaldt, The Acropolis (Oxford: Basil Blackwell, 1957), 15.

2. A. Lesky, Greek Tragedy (London: Ernest Benn Limited, 1967), 2.

3. Ibid, 6; Aristotle, Poetics (London, Dent, 1963), 1449a.

4. Aristotle, Poetics, 1963, 1449a.

5. Lesky, Greek Tragedy, 1967, 8.

6. Ibid, 10 .

7. Ibid.

8. Ibid, 41. 
emotional capacity, but not often used in other tragedies. It gives him the opportunity to formulate an important characteristic of this trilogy, which makes us realize that tragedy can be perceived simply as an actual historical phenomenon within the cultural setting that brought it into being. ${ }^{9}$ It seems that this notion refers also to the new political and social order established in fifthcentury Athens, following the atrocities of the war with the Persians, and presented by Aeschylus as the opportunity for achieving harmony after tragic suffering. In this sense Goldhill stated that tragedy thus staged its structure of the agon a division in social thought. It explores the different and competing ideals, different and competing obligations, different and competing senses of words in the developing polis, different and competing ideas of glory and success. It shows characters tailing to communicate, clinging to ideals, and tearing themselves and society apart. It discovers tension and ambiguities within the very civic ideology of democracy that is the context of tragedy's performance. ${ }^{10}$

Such an important notion, regarding tragedy as an expressive form linking religion and the social and political order of the polis, can be found as a common observation made by many scholars, and we will not elaborate on it further. ${ }^{11}$ However, it seems that for our topic the tripartite structure of Oresteia is of particular significance. Such a structure was developed by Aeschylus, probably in order to organize the successive parts of the presented action in a more elaborative manner. Despite the fact that during the sixth and the fifth century BCE, the number three was in Greek culture considered a perfect number regarding compositional structure in arts, it seems that through the construction of the trilogy Aeschylus introduced a more complex and sophisticated meaning that was particularly expressed by Oresteia.

Undoubtedly, if tragedy expresses the completeness of life in a manner of tragic epic events, through the mythological and ritual matrix, then the unification of powers governing the tripartite universe of immortals, mortals, and the dead, was one of the mayor concerns for Aeschylus. ${ }^{12}$ In this context, the analysis of the three plays constituting Oresteia, Agamemnon, The Choephoroe, and The Eumenides, could expose characteristics confirming such a notion.

In the first play the scene is set in the front of king's palace, and activities of the protagonists reflect Agamemnon's politics and decisions he made for the war and during the war. Such worldly actions nurse guilt as a prerequisite for suffering. Agamemnon, as a maker of war, was presented as sinner succumbing to persuasion for his ruin. ${ }^{13}$ His wife's revenge can be considered as retribution for the king's guilt, but her action accumulates further suffering, provoked by the terror of treason, murder and bloodshed. Clytemnestra performed an almost

9. Ibid, 12.

10. S. Goldhill, Aeschylus: The Oresteie (Cambridge: Cambridge University Press, 2012), 17.

11. H. Gordemanns, "Aeschylos: Die Tragodien," in Das Griechische Drama (Darmstadt: Gustav Adolf Seeck, 1979); K. Frank, “Aeschylos: Die Tragodien,” in Das Griechische Drama (Darmstadt: Gustav Adolf Seeck, 1979), 504.

12. D. Wiles, Tragedy in Athens - Performance Space and Theatrical Meaning (Cambridge: Cambridge University Press, 1997), 76.

13. R. Gakeen, "Aspects of dramatic symbolism: three studies in Orestia," The American Journal of Philology 76, no. 2 (1955), 127. 
ritual killing. By laying a red carpet at the palace's entrance, and by luring the king to walk across it, she actually separated Agamemnon from the earth of Argos and its symbolical power. In its deeper meaning, the carpet seems to be understood as a thing darkly pooling blood and death while overtly sheening pomp and pride. ${ }^{14}$ Thus, through the first play of trilogy, Oresteia, the world of men is characterized by political power leading into inexorable repetition of conflicts and suffering.

In the second play, The Choephoroe, the audience faces a predominant invocation of chthonic powers. The scene opens with Orestes surrounded by the altar, gravestone and burial mound of Agamemnon, and the world below the earth becomes the centre of concern. ${ }^{15}$ It seems that for Aeschylus the link between the world of the living and that of the dead is charged with strong energies, which are essentially important for the completeness of man's existence and ethical concerns. Orestes' decision to kill Clytemnestra is deeply rooted in the tradition marked by the grave of his father as the powerful source of revengeful actions. As Lesky emphasized again and again Agamemnon's aid is invoked; in true archaic fashion the dead man is imagined as a powerfully effective demon, and is conjured up with all the magic tomb ritual. ${ }^{16}$ However, Aeschylus was not presenting an isolated example, nor was the play created as a literal fiction.

According to our knowledge of the cult of the dead, particularly those who died a violent death, it seems that Aeschylus accurately presented an execution of revenge and subsequent ritual purification, traditionally performed in such cases and still valid in rituals that were practiced in Athens in the fifth century BCE and earlier. Also, the role of Apollo and the Delphic Oracle in this context was actually part of the cult. Orestes was ordered by the Delphic god to execute the revenge killing of his mother, by which the ancient custom, an inevitable obligation towards the soul of the dead, would be fulfilled. Nonfeasance of that obligation would bring about terrible misfortune to the living and the land itself, by the unrest and anger of the troubled soul. ${ }^{17}$ Nevertheless, in the play The Choephoroe Aeschylus collects and presents the most important aspects of the chthonic cults and rituals related to the dead and their immortal souls, practiced in Athens of its time. This was an important level developed in the trilogy, a step towards completing the idea of presenting human existence as a whole.

By presenting such an event in the second play, Aeschylus brings the audience to an emotional culmination. He provokes a terrifying feeling as a consequence of people's belief in the actual existence of the presented chthonic powers and inevitability of the protagonist's actions. In this sense, the appearance of the Eumenides at the end of the The Choephoroe seems to be the culmination of horror. However, the emotional gradation structured in this manner is a logical prelude to the third play, developing the feeling of redemption and reconciliation, which is introduced by a new divine and social order.

The third play, The Eumenides, opens with Orestes kneeling by the statue of

14. Ibid, 116.

15. Wiles, Tragedy in Athens - Performance Space and Theatrical Meaning, 1997, 180.

16. Lesky, Greek Tragedy, 1967, 80.

17. E. Rohde, Psyche. Seelencult und Unsterblichkeitsglaube der Grichen (Tubingen: Verlag von J.C.B. Mehr, 1925), Chapter III. 
Athena in front of the temple, an image which denotes a public space of the polis. In addition to the main event, the ultimate resolution of Orestes by the divine power, many scholars agree that this play is particularly concerned with the rising new democratic order of the polis, and its general importance. For instance, the scene of Orestes' trial could be interpreted as the moment of the founding of the Areopagus as a court of men, established in the grace of Athena herself. The process of judgment was performed according to the decrees of Areopagus also in the cases where formerly magic purification rites were required. ${ }^{18}$ Actually, it seems that Aeschylus presented the importance of establishing democratic institutions in Athens, and therefore he continued to give the tragic performance a fundamental notion of real political and social life of the polis.

It has already been acknowledged that Oresteia, which starts in the home of the family and moves to the law court of the city traverses the tensions produced by these two sites of authority in fifth-century culture, the oikos and the polis. ${ }^{19}$ In this sense, in The Eumenides Aeschylus provides a particular affirmation of the new city's order, and its new political and cultural context. Moreover, the final procession of the play, as the Furies are escorted to their new home in Athens, is staged in such a way as to recall the Athenian festival of the Great Panathenaia. So, as Athena directs the final procession of the Oresteia, the play represents the city to the city, celebrating its goddess and itself as community. ${ }^{20}$

The manner in which Aeschylus addresses and raises important questions related to the political and cultural life of the fifth-century Athenian community, seems to reflect particular aesthetic ideas developed during the classical era. The structural complexity of the integrated ideas, reflecting the existential reality of the polis and its beliefs, exposed in trilogy Oresteia, is carefully formed as a spatiotemporal system essentially inherent to Greek thinking. In its fundaments it has been attained by the cohesive power of longing for the perfection in human expression. Aeschylus' genius simply formulated that longing for classical perfection and structural complexity through the construction of a trilogy, and by means of the art of tragedy. However, his achievement seems to coincide with the second example of the classical perfection - the Acropolis of Athens as the image of the greatness of the polis.

18. Lesky, Greek Tragedy, 1967, 83.

19. Goldhill, Aeschylus: The Oresteie, 2012, 7.

20. Ibid, 52. 


\section{The Acropolis of Athens}

The political reality, the war against Persian invasion, stroked all the segments of Greek life, particularly that of the Athenians. One can consider it a process of maturing in a political and social sense, especially after conscious acceptance of the necessity of sacrificing their capital city. In this act we recognize the attitude of heroic man, as Lesky formulated it. ${ }^{21}$ This notion is crucial for our discussion. As we remember, the dignity of the fall should be accepted as the first prerequisite for tragic effect. ${ }^{22}$ Of course, in our context the definition of the tragic effect exceeds the art of poetry, and it can be accepted as an essential aesthetical and cultural expression of the new classical ethical concern.

However, such a portentous decision and its willing acceptance, reflect the second and the third prerequisites for the tragic effect, as Lesky pointed them out. The act of Athenians was extremely relevant for the world they lived in, and they suffered the consequences of it knowingly. ${ }^{23}$ However, after the deed was done, they decided to mythologize it by a new oath never to rebuild the temples destroyed by the Persians, particularly their noblest sanctity, the archaic temple of Athena Polias, located in the centre of the Acropolis. In its essence such decision was a kind of glorious reconciliation, while the remains of destroyed temples were transformed in a memorial to those who come after of the sacrilege of the barbarians. ${ }^{24}$ According to this ethical notion, the Athenians trusted that memory will restore what time must destroy. By this they introduced a particular understanding, also important for the development of new aesthetic attitude, that $d$ welling upon the past is therefore dwelling upon the present. ${ }^{25}$ This notion can be also understood as becoming the principal force of social cohesion of the polis. Conscious suffering leads to moderation of the old order which provoked the terror. Thus, memory and unification of the past and present appear to be a powerful political tool of the new order of Athens. This could be the reason why it can be considered that the classical reconstruction of the Athenian Acropolis was a project initiated and completed by the demos - by the entire community rather than one person or a group of citizens. ${ }^{26}$

However, in such a social and political context of rebuilding their most sacred site, the people of Athens advanced its architectonic structure into a highly sophisticated and complex unity. It seems that the concept of the final part of the procession of the Panathenaia was of particular influence on the new classical architectural concept. ${ }^{27}$ The procession alone can in its essence be defined as a spatio-temporal event. Actually, as part of a religious ritual of the highest order, it appears to influence the fundamental norms of peoples' movement through space,

21. Lesky, Greek Tragedy, 1967, 55.

22. Ibid, 8 .

23. Ibid, 10 .

24. Diodorus, Historical Library (London, 1814), 11.29.2.

27.

25. J. De Romilly, Time in Greek Tragedy (Ithaca, New York: Cornel University Press, 1968),

26. J. Neils, The Parthenon Frieze (Cambridge: Cambridge University Press, 2001), 25, 26.

27. R. F. Rhodes, An Architecture and Meaning on the Athenian Acropolis (Cambridge: Cambridge University Press, 1995), 44. 
in order to enable the core of a mythological event $-a$ transformation of past action into present action. ${ }^{28}$ Furthermore, Wiles reminds us of a very important fifth-century belief, concretized in architectural practice, that all spaces have their divine overseers and that spaces can never be abstract or inanimate, ${ }^{29}$ which as a general aesthetic notion influenced Aeschylus' approach toward theatrical space in the first place.

To properly analyze the characteristics of the Athenian Acropolis of the classical era important for our discussion, we should take into consideration the actual movement down the path of the sacred procession. The continuous progression of mythological and ritual activities develops during this procession, as an increase of emotional charge towards the climax of the sacred event. It is conditioned by a number of meaningful sacred sites that one encounters on the processional way.

After entering the sacred plateau, one faces the first site marked by a colossal statue of armed Athena presented as the warrior maiden, in later periods named Athena Promachos. It refers to the Athena as protector of the city. ${ }^{30}$ However, being surrounded by the spoils of war - votive presents bequeathed to mark equally those victorious and defeated - the statue seems to carry additional meaning. As the first new classical monument at the Athenian Acropolis, the statue was erected in the year $460 \mathrm{BCE}$, and at a time when the memories of the last war with the Persians were still historically active. Its position was marking the axis of the ruined Old Temple, and it is possible that it symbolically coincided with the orientation of the image.

The goddess was faced the West cardinal point of the sunset (not usual in Greek culture when placing an image of a supreme deity), and all mortals coming to Acropolis were reminded of the fruits of actions of politics and war, both the glory and the suffering. Arrivers, facing the statue, were urged to remind themselves of their past deeds, and those leaving the site were followed by the Athena's gaze, to think of what they will do in the future. In that context, the goddess was not presented only as the protector of the city, but also as an overseer and cultivator of human political activities, equally as punisher and rewarder.

Continuing down the old Panathenaic Way, the procession would reach the next sacred site on the north side of the Acropolis. It was occupied by the Erechtheion temple, according to many scholars the rightful successor of the destroyed Old Temple of Athena Polias. ${ }^{31}$ It housed the ancient and the holiest image of Athena Polias, a peaceful goddess watching over the increase of the land, ${ }^{32}$ to which the Peplos was offered on the day of the Panathenaia. ${ }^{33}$ However, in addition to the worship of the main cult of Athena Polias, Erechtheion was also a sacred place of other cults, particularly related to the founding of the city. It is the spot where Athena and Poseidon held the competition for the control of Attica,

28. Wiles, Tragedy in Athens - Performance Space and Theatrical Meaning, 1997, 114.

29. Ibid, 168.

30. C. Cuninngham, The Acropolis (The Open University Press, 1979), 15.

31. C. J. Herington, Athena Parthenos and Athena Polias (Manchester: Manchester University Press, 1955), 19.

32. Ibid, 44.

33. Ibid, 32; Neils. The Parthenon Frieze, 2001, 173. 
witnessed by the sacred olive tree and the pond with salt water, still visible in the Classical period. Under this temple were the graves of the first mythological kings of Athens, and near it, on the north slope, was the place where, according to the last scene in Aeschylus play The Eumenides, Athena calmed the anger of the Furies. After that the old chthonic deities were no longer present just as the horror of the underworld, but also the powers of blessing that slumber in the depths of the earth. ${ }^{34}$

For our discussion, the named functions of Erechtheion, as the second site in the spatio-temporal progression across the plateau of the Acropolis of Athens, are of particular importance. It is a site that predominantly hosted by Athena cultivated chthonic powers, from which came the prosperity and the increase of the city and land. Through it the new community of the polis achieved an essential and direct connection with its mythical past, also affecting the people's political and economical existence, cults, rites and customs. This temple is considered a complex aggregation of myths, not only in regard to the founding of the city of Athens, ${ }^{35}$ but also as a constant source of benevolent and powerful energies helping the development of polis.

Before the completion of the Great Temple, in later periods named as Parthenon, the ritual climax of the Panathenaia procession, the offering of Peplos to the ancient image of Athena Polias, i.e. the one dwelling on the polis, was probably the last encounter with the holy sites of the goddess. However, there is still uncertainty regarding how the Parthenon was introduced into the great festival after its completion. There is no evidence of the particular cult at that site, nor any association with traditional priesthood. ${ }^{36}$ Even the name Parthenos, attached to the great statue made by Phidias, was not an official title, but a popular name. ${ }^{37}$

However, it is significant that after Parthenon was erected as Athena's second temple, it become also her third holy site at the Acropolis. Since two abovementioned sacred sites of Athena carried important attributes of her divine power, it seems correct to assume that the third and newest one also contained meaning important for the accomplishment of the communal and cultural cohesion of the polis. One can feel a premonition that it was revered as a divine monument of the new order of the city, as a unique mythological, ritual, and political entity forged through glorious historical events at the beginning of the fifth century. It also reflected military and financial power that Athens had developed, and its dignity as a cosmopolitan centre of the Greek world. This idea is certainly visible in the sculptural program of the Parthenon, and it has been analyzed in detail by several important scholars. ${ }^{38}$ There is a strong notion that by its entire structure, both architectural and sculptural, the Parthenon visibly represents all the important aspects and references to democratic Athens and its new institutions.

34. Lesky, Greek Tragedy, 1967, 84.

35. Rhodes, An Architecture and Meaning on the Athenian Acropolis, 1995, 140.

36. Neils, The Parthenon Frieze, 2001, 26.

37. Herington, Athena Parthenos and Athena Polias, 1955, 6.

38. Neils, The Parthenon Frieze, 2001; O. Kobin, "Democracy and Imperialism in the Panathenaic Processions: The Parthenon Frieze in its Context," in Proceedings of the International Conference 'The Archeology of Athens and Attica under the Democracy. American School of Classical Studies of Athens 1992. Oxbow Monograph 37 (1994), 143-150. 


\section{Conclusions}

A complex tripartite sacred structure, which addresses the most important attributes of Athena, can be identified at the Athenian Acropolis. These attributes are closely linked to the essential aspects of the religious and political organization of the polis. It can be considered a kind of invocation of divine attributive names, so important in the life of Greek cults, because who really wants to be heard by the god must call him by the right name, and if the god has several they must all be pronounced. ${ }^{39}$ It seems that for the fifth-century citizens of Athens it was particularly important, due to their fresh memory of the atrocities of the GrecoPersian War, to put all activities essential for their prosperous life in the future under supreme control of Athena. In that context Athena needed to be called upon, as overseer of the political actions and mortals, as the divine mediator between the polis and energy of chthonic powers and ancient rituals, and as the establisher and keeper of new democratic order.

Furthermore, there is a strong feeling that the essential meanings of each of the three parts of the structure presented at the Acropolis, by their nature and the way of spatio-temporal appearance, coincides with the previously analyzed structure and meaning of the Oresteia trilogy. In both examples, through the first part of their compositional structure, spectators encounter the world of men, represented by their activities and consequences provoked by them, as in the play Agamemnon, or through the memories of war, victorious or disastrous, offered to Athena Promachos. The appearance of unavoidable powers of the chthonic world, where its energies are presented as still governing the activities of mortals, is the crucial point of the second play in Aeschylus' trilogy, as is the case with the cults of the temple of Erechtheion. The glorious celebration of the new order of polis and the reconciliation of accumulated suffering appears as the closing idea of both analyzed tripartite structures of Orestheia and Acropolis. In both structures, Athena is presented as the divine and supreme power of cultivation and transformation of old customs and politics into the city's democratic institutions.

However, it seems that the importance of the above-mentioned tripartite structures was not an isolated approach in expressing symbolical and aesthetical meanings through art and architecture, particularly at the Acropolis of Athens. In the analysis of the general structure of the Parthenon frieze, Neils indicated three important parts of the narrative representing the Panathenaia, as progressing through space and over time. ${ }^{40}$ Actually, there are presentations of following events: first of the preparations for the procession, second of the procession itself, and at the end on the east side of the temple, the assembly of deities and the end of the ritual. This example clearly shows that the idea for attaining compositional harmony in the classical period of the Greek culture, involves in a higher degree also the tripartite principle of structuring, and not only as a Platonic ideal.

This kind of perceptual organization of an artwork, as aesthetic forming of

39. Lesky, Greek Tragedy, 1967, 74.

40. Neils, The Parthenon Frieze, 2001, 51. 
observer's development of empathy through particularly exposed meanings, can be also further recognized, for instance in three main types of symbolic imagery, as defined by Gakeen. In analyzing aspects of dramatic symbolism, he defines the verbal imagery, the imagery of action, and of scene. ${ }^{41}$ However, a tripartite relation indicated by Wiles, the one between a temple, an altar and playing area can be from a particular importance for our discussion. ${ }^{42}$ It reminds us that tragedy and theatre are actual representations of real spatial and temporal cult and political performances organized in the city of Athens.

In that sense, one more similarity between our two examples can be pointed out, involving the circular spatial organization of the main activities. Originating from ritual activity, drama inherited the circular organization of the orchestra, which was called thymele - to sacrifice. The centre of it, around which the chorus and actors move, was also used as an altar whenever dramatic action called for it. ${ }^{43}$ Like in rituals, where people assembled circularly around the altar, so in theatre the members of the community are placed around the orchestra. In both cases the dramatic event, taking place in the centre of the space, was producing a powerful effect of social integration. ${ }^{44}$ During the theatrical performance audience also becomes a strong political entity. ${ }^{45}$ This was the reason why at the end of the Oresteia trilogy, Aeschylus was able to present Athena's speech to the audience, as an assembly unified in cultural and political life. It is a kind of self-addressing of the polis through drama, as the very product of the polis. ${ }^{46}$

Similarly, reaching the plateau of the Athenian Acropolis, the Panathenaian procession actually moved around the holy ground where the ruins of the Old Temple were exposed. It was the centre of historical memory, an orchestra of past activities, unifying the community politically, culturally, and ritually. Like in theatre, on the Acropolis the assembly space was transformed into a political space. Wiles defined this transformation as a particular invention of the fifth century. ${ }^{47}$ In fact, it seems that the analyzed similarity could be perceived as a part of a larger practice in fifth-century Athens. Referring again to Wiles: in many spheres of Athenian democratic activity we see spatial relationships organized in terms of a fixed centre and a more or less circular periphery. ${ }^{48}$

The noted similarities in the structures and symbolical meanings of their parts, between Aeschylus' trilogy and Acropolis of Athens, could not be explained through formal influences of one example on the other, or even as having one particular common artistic model. Of course, several scholars emphasized the

41. Gakeen, "Aspects of dramatic symbolism: three studies in Orestia," 1955, 114.

42. Wiles, Tragedy in Athens - Performance Space and Theatrical Meaning, 1997, 26.

43. F. Rainer, "Drama and Ritual," in Drama and Religion (ed.) James Redmond (Cambridge: Cambridge University Press, 1983), 170; H. Scolnicoy, "Theatre Space and the Theatrical Space Without," in The Theatrical Space. Themes in Drama (ed.) James Redmond (Cambridge: Cambridge University Press, 1987), 12; Wiles, Tragedy in Athens - Performance Space and Theatrical Meaning, 1997, 58.

44. Rainer, "Drama and Ritual," 1983, 169.

45. Wiles, Tragedy in Athens - Performance Space and Theatrical Meaning, 1997, 38.

46. Lesky, Greek Tragedy, 1967, 86.

47. Wiles, Tragedy in Athens - Performance Space and Theatrical Meaning, 1997, 35.

48. Ibid, 72. 
supremacy of Aeschylus' interpretation and structure of Oresteia over other great Athenian artistic and architectural projects of the second half of the fifth century. ${ }^{49}$ However, it seems that our two examples coincide by belonging to particular cultural and aesthetical expressions of ritually and politically configured myths, of existential importance for the life and development of cohesion of the polis.

Namely, both analyzed examples express the emotional and ritual culmination of the two most important festivals of the city of Athens: the tragedy performed in the theater belongs to the festival of the Great Dionysia, and Acropolis to the Great Panathenaia. Together they encompass all fulfillments of the expectations of the citizens of fifth-century Athens, based on their religious and political beliefs. Through the analyzed structure of the symbolical meanings in Oresteia and in the composition of the Acropolis, a mythical necessity, of importance to human existence, has been achieved: the fundamental link between all three worlds (the underworld, the world of men, and the world of gods).

\section{Bibliography}

Aristotle. Poetics. London: Dent, 1963.

Cuninngham, C. The Acropolis. The Open University Press, 1979.

De Romilly, J. Time in Greek Tragedy. Ithaca, New York: Cornel University Press, 1968.

Diodorus. Historical Library. London, 1814.

Frank, K. "Aeschylos: Die Tragodien" [Aeschylus: The tragedies.] In Das Griechische Drama. Darmstadt: Gustav Adolf Seeck, 1979.

Gakeen, R. "Aspects of Dramatic Symbolism: Three Studies in Orestia." The American Journal of Philology 76, no. 2 (1955).

Goldhill, S. Aeschylus: The Oresteie. Cambridge: Cambridge University Press, 2012.

Gordemanns, H. "Aeschylos: Die Tragodien." [Aeschylus: The tragedies.] In Das Griechische Drama. Darmstadt: Gustav Adolf Seeck, 1979.

Herington, C. J. Athena Parthenos and Athena Polias. Manchester: Manchester University Press, 1955.

Kobin, O. "Democracy and Imperialism in the Panathenaic Processions: The Parthenon Frieze in its Context." In Proceedings of the International Conference 'The Archeology of Athens and Attica under the Democracy. American School of Classical Studies of Athens 1992. Oxbow Monograph 37 (1994).

Lesky, A. Greek Tragedy. London: Ernest Benn Limited, 1967.

Neils, J. The Parthenon Frieze. Cambridge: Cambridge University Press, 2001.

Rainer, F. "Drama and Ritual." In Drama and Religion. Edited by James Redmond. Cambridge: Cambridge University Press, 1983.

Rhodes, R. F. An Architecture and Meaning on the Athenian Acropolis. Cambridge: Cambridge University Press, 1995.

Rodenwaldt, G. The Acropolis. Oxford: Basil Blackwell, 1957.

Rohde, E. Psyche. Seelencult und Unsterblichkeitsglaube der Grichen [Psyche. Soul cult and immortality beliefs of the Greeks.] Tubingen: Verlag von J.C.B. Mehr, 1925.

Scolnicoy, H. "Theatre Space and the Theatrical Space Without." In The Theatrical Space. Themes in Drama. Edited by James Redmond. Cambridge: Cambridge University Press, 1987.

49. Herington, Athena Parthenos and Athena Polias, 1955, 54. 
Vol. 5, No. 1 Mako: The Aesthetics and Attainability of Cultural Cohesion ...

Wiles, D. Tragedy in Athens - Performance Space and Theatrical Meaning. Cambridge: Cambridge University Press, 1997. 